\title{
INFLECTED INFINITIVES IN BRAZILIAN Portuguese As An Argument Both CONTRA AND In FAVOR OF A MOVEMENT ANALYSIS OF CONTROL
}

\author{
Infinitivos flexionados em Português Brasileiro como \\ argumento tanto contra quanto a favor de uma \\ análise do movimento do controle
}

\author{
Marcello Modesto*
}

\section{INTRODUCTION}

Since the beginning of the Minimalist Program (MP), Control has been a hot topic of debate because classical analyses (involving government, etc.) cannot be maintained in that new theoretical scenario. Minimalist analyses of Control vary from mild modifications of the classical (Government and Binding) view to radically different analyses, but none of them, in my view (see discussion in section 1 below), satisfactorily explains the Control phenomenon. Perhaps the most ambitious and theoretically far-reaching of these new analyses is the one in Hornstein 1999, where Control is seen as raising to a è-position. Lately, then, a very lively debate has taken place between those who are against or in favor of analyzing Control as Movement (cf. Culicover and Jackendoff 2001, Boeckx and Hornstein 2003, Landau 2003, Boeckx and Hornstein 2004, among others). In this work, I will present data mainly from Brazilian Portuguese, which shows clearly that Control cannot be derived by Movement in certain cases. I will also present, however, arguments in favor of the claim that, in fact, Movement is involved in the derivation of some Control structures. 


\section{Control Within The Minimalist Program}

Chomsky and Lasnik (1995), in what came to be the seed of the MP, argued that classical analyses of Control could not be maintained, and that the distribution of PRO would be better explained if we assumed that PRO was the sole beneficiary of a null Case, the Case assigned by non-finite INFL. Such idea persists today in most "well-behaved" Minimalist analyses of Control (see Martin 2001, Radford 2004, among others). However, this school of thought within the MP has failed to provide the details of the derivation of Control structures. Let us suppose, with Radford (2004), that PRO comes into the derivation of the sentence "They have decided [PRO to help you]" carrying interpretable $3^{\text {rd }}$ person and Plural features, since it refers back to "they". PRO is an active goal since it has an unvalued (and so uninterpretable) Case feature. When non-finite I enters the derivation, its unvalued phi-features will probe the c-command domain and find PRO. After Agree has taken place, all uninterpretable features will be valued and deleted, including the null Case of PRO, and PRO will be merged in the top of the structure to satisfy the EPP feature of I. Such an analysis raises the question why one cannot take PRO from the lexicon with any phi-features, $1^{\text {st }}$ person singular, for instance, and interpret the sentence with the meaning "they have decided that I will help you". It is clear that nothing would prevent that structure to converge with that meaning. Suppose then that PRO has only unvalued phi-features. It is unclear if agreement can hold between two unvalued features. Moreover, assuming that it is possible, we would have to invoke default number/person valuation conditions and the interpretation of PRO, referring back to its controller would be a completely unexplained fact.

Landau $(2000,2004)$ claims that the interpretation of PRO is given by the operation Agree, which applies between PRO and its controller ${ }^{1}$. In his system, PRO comes into the derivation with unvalued, though interpretable phi-features, which are then valued by Agree with the controller (even if indirectly). Since $C$ is crucially involved in deriving partial and exhaustive control in his theory, the phi-features of PRO must be interpretable; otherwise, they would not be accessible to a probe outside its phase. Landau's system has some unclear details, especially those related to the agreement of the [R] feature between PRO and its controller (or the functional head that agrees with its controller), but at least it tries to draw a complete picture of what 
Control would look like in a Minimalist environment where PRO exists.

A radically different proposal within the MP is that of Hornstein (1999). He claims that PRO is a strange animal in the Minimalist ecosystem and, therefore, its existence can only be asserted by hard evidence, which he does not believe exists. Getting rid of PRO would be easy, Hornstein says, if one makes the (in principle very Minimalist) assumption that Movement can target theta-positions. Control would, then, boil down to raising, with the difference that the controller would be remerged into a theta-position, before reaching its Case checking position. The interpretation of controlled null subjects would then be just a reflex of the movement chain between the subject position of the infinitival clause and the position of the controller. The proposal, let us call it the Movement Theory of Control (MTC), gained followers due to its simplicity. However, not few researchers pointed out that the view was reductionist and equivocated. Landau 2003, for instance, offers a comprehensive critique of the MTC, to which Boeckx and Hornstein 2004 replies, resolving some but not all the issues. I will then mention the problems that, I think, are not properly addressed in Boeckx and Hornstein 2004.

Landau correctly notes that the MTC overgenerates nonexistent structures and interpretations in Control across passive structures. If the derivation of (1a) is exactly like that of (1b), except for the extra step in the matrix VP of (1a), where the subject gets the matrix agent theta-role, nothing seems to prevent generating sentence (1c), with interpretation (1d) and derivation (1e):

(1) a. John $\left[_{\mathrm{VP}}<\mathrm{John}>\right.$ hopes $\left[_{\mathrm{IP}}<\mathrm{John}>\right.$ to $\left[_{\mathrm{VP}}<\mathrm{John}>\right.$ win the game ]]]

b. John seems $\left[_{\mathrm{IP}}<\right.$ John $>$ to have $\left[_{\mathrm{VP}}<\right.$ John $>$ won the game ]]]

c. *John was hoped to win the game.

d. It was hoped John would win the game.

e. John was hoped [ $<$ John $>$ to $[<$ John $>$ win the game ]]

(1c) is structurally indistinguishable from (1b), where raising creates a chain with one theta-role. The combination of raising and passivization of the embedded subject is attested in ECM constructions such as (2):

(2) John was expected $\left[_{\mathrm{IP}}<\mathrm{John}>\right.$ to $\left[{ }_{\mathrm{VP}}<\mathrm{John}>\right.$ win the game ]]

The question is, then, how to rule out (1e) while still allowing (1a, 
b) and (2)? The solution offered by Hornstein (2000) involving C incorporation, which is prevented in passives, is not an explanation until we know why $\mathrm{C}$ cannot incorporate onto passive verbs. Boeckx and Hornstein (2004) simply dismiss the problem on the face of the contrast between $(3 a-b)$ and $(3 c-d)$ :

(3) a. John hoped that Mary would come.

b. That Mary would come was hoped. / It was hoped that Mary would come.

c. *John hoped Mary.

d. *Mary was hoped.

However, that hope cannot take a non-clausal complement is beside the point. hope can certainly be passivized, as seen in (3b). It is also clear that the complement $\mathrm{CP}$ does not need Case, witnessed by the grammaticality of the second version of (3b). Lastly, (2) shows that movement of the subject can take place from the infinitival clause. It is then completely unexpected that (1c) cannot be generated from the partial derivation (4). Note that, if what prevents extraction in (4) is the fact that control complements are CPs, and CPs are phases, blocking extraction; then extraction should be blocked in (1a) as well.

(4) $\left[_{I P}\right.$ was $\left[{ }_{V P}\right.$ hoped $\left[{ }_{I P}\right.$ John to $\left[{ }_{V P}<J o h n>\right.$ win the game $\left.\left.\left.]\right]\right]\right]$

Another argument against the MTC, which is ignored by Boeckx and Hornstein, is the one bearing on Case concord in Icelandic. It goes like this: Sigurðsson (1991) has argued convincingly that PRO in Icelandic bears Case (which, in fact, motivated the null Case analysis of Control). One of his arguments is based on the observation that: (a) certain predicates determine quirky Case on their subjects; (b) floating quantifiers agree in Case with their subjects. Landau then affirms that it is possible to detect the Case of PRO by the Case of the floating quantifier. Consider the paradigm in (5):

(5) a. Strákarnir vonat til [að PRO vanta ekki alla í skólann]. the.boys.NOM hope for to PRO lack not all.ACC in the.school 'The boys hope not to be all absent from school.'

b. Strákarnir vonat til [að PRO lei ðast ekki öllum í skóla]. the.boys.NOM hope for to PRO to.be bored not all. DAT in school 'The boys hope not to be all bored in school.'

c. Strákarnir vonat til [að PRO verða allra getið 
í ræðnnie].

the.boys.NOM hope for to PRO be all.

GEN mentioned in the.speech

'The boys hope to be all mentioned in the speech.'

The predicates lack (be absent), be bored and be mentioned in Icelandic mark their subjects with quirky case, which in the sentences in (5) appears on the floating quantifier. The necessary assumption to explain such a paradigm is that PRO bears accusative in (5a), dative in $(5 b)$ and genitive in $(5 \mathrm{c})$. This alone undermines the MTC since it takes the controlled position to be Caseless. Boeckx and Hornstein (2004) say that, instead of undermining the movement approach, the Icelandic facts do just the opposite. Then they continue:

The facts [in Icelandic MM] divide into two basic groups: instances of quirky Case concord and instances of structural Case concord. The former require some theoretical adjustments with regard to multiply Case-marked DPs in order to be incorporated into any account of Control... The latter are very easily integrated into a movement approach but are quite surprising given a PRO-based theory.

In view of the fact that Boeckx and Hornstein do not mention what those "theoretical adjustments" would be like, their dismissal of Landau's argument is too hasty. They imply that quirky Case concord is not a problem for them since it is a problem for any theory of Control, however, those data are expected in a system like Landau's $(2000,2004)$, where PRO receives any "normal" Case (structural or quirky) and not null Case. The argument is still more devastating for the MTC when one observes that there is no Case mismatch in raising constructions (the data is from O'Neil 1997:109, apud Landau 2003:492, attributed to Höskuldur Thráinsson)²:

\footnotetext{
The argument becomes very tricky here. Since the subject position of the infinitival clause is taken to be a Case position, one has to assume, as Landau (2004) does, that $\mathrm{I}^{0}$ in $\mathrm{ECM} /$ raising complements is defective in some way, and, therefore, unable to check Case of its subject. The problem, then, is that Landau's theory also does not explain the paradigm in (6) (nor would Hornstein), since the subject DP seems to be checking Case in the downstairs position. Icelandic seems to show that the complement of raising predicates is not defective and that Case is indeed checked downstairs. Movement to matrix subject position would then be solely driven by the EPP feature of raising verbs. That immediately raises the question why sentence (i) below is not acceptable:

(i) $\quad{ }^{*}$ There/it seems John to be tired.

Solving any of these problems is outside the scope of this work.
} 
MODESTO. M. Inflected Infinitives In BRAzILIAN PoRtuguese...

(6) a. Strákarna virðast [t vanta ekki alla í skólann]. the.boys.ACC seem to.lack not all.ACC in the.school 'The boys seem not to be all absent from school.'

b. Strákunum virðast [t lei ðast ekki öllum í skóla]. the.boys.DAT seem to.be bored not all.DAT in school 'The boys seem not to be all bored in school.'

c. Strákanna virðast [t verða allra getið í ræðnnie]. the.boys.GEN seem to.be all.GEN mentioned in the.speech 'The boys seem to be all mentioned in the speech.'

The reason why Boeckx and Hornstein dismiss such a compelling argument against the MTC so quickly, I believe, is that structural Case concord provides arguments in favor of the MTC:

(7) Jón bað Bjarna að koma einan.

Jon.NOM asked Bjarni.ACC to come alone.ACC

If I understand Boeckx and Hornstein's reasoning correctly, they are claiming that structural Case concord, like the one seen in (7), provides confirming evidence for the MTC because to come, in Icelandic, assigns Case structurally to its subject (i.e. nominative) in non-finite clauses. The surfacing of the floating quantifier bearing accusative, then, is readily captured by the MTC but it is rather mysterious under classical analyses of Control. If that was their reasoning, it seems to be correct.

There is an important difference between the cases treated by Landau, and that given by Boeckx and Hornstein. The latter involves object Control, while the former involve subject Control. Why should that matter? In the remaining of this paper, I will argue that movement from a controlled subject position to another subject position is impossible in Brazilian Portuguese (BP) (and perhaps universally), but movement to an object position is indeed possible. If I am correct, then, BP will shed some light on why Icelandic seems to argue in favor and against the MTC at the same time, and both languages will constitute evidence that movement is indeed the preferred strategy to derive Control structures but PRO, nevertheless, cannot be assumed not to exist.

\section{INFLECTED INFINITIVES IN BP}

The debate about the MTC, and about Control in general, can profit a lot from including data from languages like (Brazilian) Portuguese, in 
which infinitival forms may be marked by agreement features (the famous "inflected infinitive"). This is because, since agreement is visible, Portuguese let us know exactly if and when a verb agrees with its subject and if that subject shares the same agreement features with its controller. The MTC predicts that infinitival forms should always agree with the controller of its own subject (since the latter has been moved from a position in which agreement with the verb is necessary, i.e. Spec IP. The facts, however, point to a different direction. Inflection is always obligatory when the subject is overtly expressed but optional and sometimes ungrammatical in control structures, which seems to provide evidence against the MTC. Here are the facts: infinitives are necessarily inflected in subject clauses, purpose clauses and what seems to be ECM contexts, as shown in (8a-c); usually inflected (but possibly not) in object Control cases (8d); and absolutely never inflected in subject control cases $(8 \mathrm{e})^{3}$ :

(8) a. Os meninos sair*(em) à noite preocupa suas mães. the boys to.go.out-3pl at night worry-3sg their mothers

b. Eu comprei esse livro pros meninos ler*(em). I bought-1 sg this book for.the boys to.read-3pl (it).

c. Eu lamentei os meninos chegar*(em) tão tarde. I resented-1sg the boys to.arrive-3pl so late

d. Eu convenci os meninos a tomar(em) banho. I convinced-1sg the boys Prep. to.take-3pl bath

e. Os meninos querem nadar $\left({ }^{*} \mathrm{em}\right)$. the boys want-3pl to.swim-3pl

The paradigm in (8) shows several things. Firstly, since an overt subject is able to occupy the subject position of the (inflected) infinitival clause (in (8a) for instance) without the presence of any visible case marker, it shows that the inflected infinitival $\mathrm{I}^{0}$ is able to assign Case to its subject. Sentence (8c) confirms that claim when we realize that it is not an ECM structure. Unlike what happens with ECM verbs like English expect, verbs such as lamentar (to resent, to lament) in Portuguese (a) do not assign accusative to the subject of its complement (see (9a)); and (b) they take the whole complement clause as its surface subject when passivized (see $(9 \mathrm{~b}, \mathrm{c}))$ :
(9) a. Eu lamentei eles chegar*(em) tão tarde. I resented-1sg they.NOM to.arrive-3pl so late

\footnotetext{
As we will see below in more detail, (8c) is not an ECM structure. (8d) is an object Control structure when the infinitive does not present agreement inflection, but a kind of ECM structure when the verb is inflected.
} 
MODESTO. M. Inflected Infinitives In BRAZILIAN PoRtuguese...

b. *Eles foram lamentados chegar(em) tão tarde. They were resented to.arrive $(-3 \mathrm{pl})$ so late

c. Eles chegar*(em) tão tarde foi lamentado (por todos). They to.arrive- 3 pl so late was resented (by everybody)

The reason why inflected infinite clauses cannot be used as main clauses is that, as observed by Raposo (1987), those clauses themselves seem to require Case, which is probably due to the nominal character of the infinitive. Confirming evidence is provided by ( $8 \mathrm{~d}$ ) in which a dummy case marker, the preposition "a", is inserted before the complement clause, since accusative Case is assigned to the other internal argument of the matrix verb, the DP "os meninos".

The contrast between $(8 \mathrm{a}-\mathrm{c})$ and $(8 \mathrm{e})$ is also very telling. (8a-c) seem to indicate that agreement is obligatory when an overt DP occupies the subject position of the infinitival clause. If the subject in (8e) moves from the non-finite clause into the matrix VP, as it would be the case under the MTC, one should expect number and person agreement to be required (or at least possible) in (8e), contrary to fact. The contrast between ( $8 \mathrm{a}-\mathrm{c})$ and $(8 \mathrm{e})$, then, argues against a movement analysis.

However, what about the contrast between (8d) and (8e)? (8e) seems to show that PRO is always specified as singular, irrespectively of its controller's phi-features; or it may be the case that PRO has unvalued phifeatures and so the verb surfaces with default agreement. Be it as it may, the fact that agreement on the infinitive is possible in (8d) leads us to suppose that PRO is not (always) the subject of the complement clause in Object Control structures. When the infinitive agrees with the controller, one is led to suspect that the verb has been in an agreement configuration with the controller at some point of the derivation. Therefore, (8d), at least in its version with agreement, seems to argue in favor of the MTC.

Concluding, BP seems to provide arguments that the MTC is correct when one is dealing with Object Control, but wrong when one is dealing with Subject Control.

\section{Solving The PARAdox}

The facts discussed in the last section show that there seems to be movement from the subject position of an infinite clause to object position of the main verb, but not to the subject position of the main verb, in Control structures. In the remaining of this work, I will argue that BP data indicates that the MTC is basically correct: grammar resorts to movement, and avoids 
the use of pronouns, whenever it can. Movement may apply from the subject position of an infinite clause to the object position of the matrix verb, but not to its subject position. Object Control and ECM verbs, therefore, will be explained by very much the same mechanism, with the difference that a second theta-role is "picked up" by the argument in the first case, just like in Hornstein (1999). Subject Control, however, will depart from raising in that it does not involve movement of the controller but the more familiar relation between it and PRO.

The reason for the exclusion of movement from subject position to subject position in BP can be explained in a straightforward manner if one assumes that a lexical entry enters the derivation with Case feature values already assigned. So, uninterpretable Case features are made inactive in a derivation if the head containing that features enters into an Agree relation with a phi-complete head that is able to check that value of Case. Let us review the sentences in (8) discussed above in light of this new assumption.

(10) a. Os meninos sair*(em) à noite preocupa suas mães. the boys to.go.out-3pl at night worry-3sg their mothers

b. Eu comprei esse livro pros meninos ler*(em). I bought-1sg this book for.the boys to.read-3pl (it). c. Eu lamentei os meninos chegar*(em) tão tarde.

In sentences (8a-c), repeated in (10), the embedded subject os meninos is taken from the lexicon with nominative Case and it is then merged with the verbal head or a light verb, depending on the case, checking the internal or external theta-role. When infinitival inflection is merged, since Portuguese has inflected infinitives, it contains unvalued phi-features. Matching of features between the subject DP and the inflection will check nominative Case on the former and value the phi-features of $\mathrm{I}^{0}$, eliminating all uninterpretable features and causing the infinitive to be spelled out inflected for plural. Consider now (8e), repeated here as (11):

(11) Os meninos querem nadar(*em). the boys want $-3 \mathrm{pl}$ to.swim-3pl

The DP os meninos is again taken from the lexicon bearing nominative Case. Let us suppose that the DP is merged with the embedded verb, as it would be according to the MTC. Infinitival I ${ }^{0}$ will Agree with the subject DP and check nominative Case, deleting it. The DP will then become inactive and there will be no DP able to check the external theta-role of the 
matrix verb or the phi-features of the matrix $\mathrm{I}^{0}$. Let us suppose then, that the subject is taken with any other Case, accusative for instance. Agree between $\mathrm{I}^{0}$ and the subject may check the phi-features of $\mathrm{I}^{0}$ but Case of the subject remains unchecked and therefore active. The DP is then remerged with the matrix verb and then with matrix $\mathrm{I}^{\circ}$. Again, Agree may delete the phi-features of $\mathrm{I}^{0}$ but it cannot delete accusative Case of the DP. The derivation then crashes. The only possible derivation, then, is the one in which the numeration contains PRO. PRO either has invariable 3rd person singular feature values; or it may also have unvalued phi-features. In the latter case, features of PRO and $\mathrm{I}^{\circ}$ receive a default value. This Case "conspiracy" is then responsible for obligatory agreement in (10a-c) and obligatory lack of agreement in (11).

The most interesting case, however, is Object Control, exemplified in (12), where agreement is not obligatory.

(12) Eu convenci os meninos a tomar(em) banho. I convinced-1sg the boys PRP. to.take-3pl bath

Assuming that the DP os meninos is merged with the embedded verb, if it is taken with nominative Case, Agree with infinitival $I^{0}$ would make the DP inactive and the derivation would crash since the matrix verb would not assign one of its theta-roles. If, however, the DP is taken bearing accusative, Agree with infinitival $\mathrm{I}^{\circ}$ would not make it inactive. The DP could then be remerged with the matrix verb, valuing its features and then having its Case checked by $v$. The derivation converges. This derivation will only generate the sentence with agreement on the embedded verb. Another possible derivation will be one in which the numeration contains PRO, which will derive the sentence with no inflection on the infinitive. Note that the two derivations are not comparable, then.

Evidence showing that there are in fact two possible derivations for (12) comes from the fact that only the derivation involving PRO can be passivized.

(13) Os meninos foram convencidos a tomar $\left({ }^{*} \mathrm{em}\right)$ banho. the boys were convinced-m-pl PRP. to.take(*-3pl) bath

Consider what goes wrong with the derivation involving movement. If the DP is taken with accusative Case, neither the embedded nor the matrix inflection will be able to delete it and the derivation will crash. If the DP is taken bearing nominative, the embedded inflection will check its Case, the DP will be inactive and the derivation will crash at the matrix level. The only 
possible derivation, then, is the one in which PRO is the subject of tomar and the DP os meninos is merged with the verbal participle convencidos. In that derivation, there is no agreement between the infinitive and the controller. Sentence (13), then, provides strong evidence in favor of the Case conspiracy advocated here in determining when an infinitive may be inflected. It seems that always when the controller ends up in subject position, the movement derivation is not allowed.

\section{OTHER LANGUAGES}

It is easy to imagine how the analysis proposed here would apply to languages with no inflection on infinitives. In English, for instance, the same Case conspiracy would make Subject Control structures with movement impossible to derive. Nevertheless, Object Control, in principle, could involve movement, making the difference between ECM and Control verbs spurious. The impossibility of Subject Control being derived by movement explains why Control cannot happen across passives (see discussion of examples in (1) above) as shown in (14).

(14) *John was hoped to win the game.

Icelandic presents a bigger challenge for the analysis presented here. Case concord facts such as (7) above, repeated here as (15), are expected.

$$
\text { (15) Jón bað Bjarna að koma einan. }
$$

Jon.NOM asked Bjarni.ACC to come alone.ACC

The matrix object could have been generated as the subject of the infinitive but, since it bears accusative, it remains active and can be remerged with the matrix verb. However, when the embedded verb attributes quirk Case to its subject, the theory presented here would lead one to expect that there should be Case concord between the controller and the embedded floating quantifier (i.e. they all should be nominative). That is because, assigning quirk Case, those verbs would free the derivation from the Case conspiracy which bans Subject Control by movement. The fact that they do not seem to indicate that the proposal presented here may not be the entire story. Subject Control by movement may be banned (maybe universally) for some other reasons as well. 
MODESTO. M. Inflected Infinitives In BRAziLian PoRtuguese...

\title{
6 CONCLUSION
}

I have tried to show that data involving inflected infinitives in Brazilian Portuguese strongly argues against the MTC with respect to Subject Control. I have argued that the reason is related to the fact that lexical items are taken from the lexicon with a Case feature (although uninterpretable) already assigned; and since both subject positions can check nominative, Subject Control by movement derivations always crash. Object Control, on the other hand, since the landing site of the controller will check a different Case feature (other than nominative), may be derived by movement. Data from Icelandic, however, seem to indicate that Subject Control can never be derived by movement, even if the landing site of the controller checks a different Case than the infinitival verb. This may imply that there are other things at play here besides Case, or maybe that the explanation given here is on the wrong track. Even in that case, the point made here about the impossibility of deriving Subject Control structures by movement still stands, both in BP and Icelandic.

The evidence in favor of the MTC comes from the fact that infinitives may (and usually are) inflected in BP when the controller is the matrix Object. However, since Object Control may also be derived with a PRO subject (allowing passivization of Object Control verbs in BP), evidence in favor of the MTC may be too feeble to be taken into account. In that case, of course, some other explanation for the agreement facts in BP has to be found.

\begin{abstract}
This work shows that BP data strongly argue against the movement theory of Control w.r.t. Subject Control but, surprisingly, provide arguments in favor of the same MTC w.r.t. Object Control. I argue that movement is usually the means to achieve Control structures; however, due to Case reasons, movement from a subject position cannot target another subject position.

Key-words: Control; movement; Brazilian Portuguese; Icelandic.
\end{abstract}

\section{RESUMO}

Este trabalho mostra que dados do PB indicam fortemente que a teoria de Controle por Movimento está errada, no que concerne 
Controle de Sujeito. Surpreendentemente, dados da mesma língua indicam que essa teoria está certa, quando se considera Controle de Objeto. A proposta é de que movimento é geralmente usado para derivar estruturas de controle, entretanto, por razões Casuais, movimento não pode partir de uma posição de Sujeito para outra posição de Sujeito.

Palavras-chave: Controle; movimento; português brasileiro; islandês.

\section{REFERENCES}

BOECKX, C.; HORNSTEIN, N. Movement under Control. Linguistic Inquiry 35, p. 431-452, 2004.

Reply to "Control is not movement". Linguistic Inquiry 34, p. 269-280, 2003.

CHOMSKY, N. The Minimalist Program. Cambridge/Mass.: MIT Press, 1995.

The Minimalist Program. Cambridge/Mass.: MIT Press, 1995. p. 13-127.

CHOMSKY, N.; LASNIK, H. 1995. The theory of principles and parameters. In: CULICOVER, P.; JACKENDOFF, R. Control is not movement. Linguistic Inquiry 32, p. 493-512, 2001.

HORNSTEIN, N. Movement and control. Linguistic Inquiry 30, p. 69-96, 1999.

. On A-chains: A reply to Brody. Syntax 1, p. 129-143, 2000.

LANDAU, I. Elements of Control. Dordrecht: Kluwer, 2000.

. Movement out of Control. Linguistic Inquiry 34, p. 471-498, 2003.

. The Scale of finiteness and the calculus of Control. Natural Language and Linguistic Theory 22, p. 811-877, 2004.

MARTIN, R. Null case and the distribution of PRO. Linguistic Inquiry 32, p. 141-166, 2001.

O'NEIL, J. H. 1997. Means of Control: Deriving the properties of PRO in the Minimalist Program. Dissertation (Doctoral) - University of Maryland, College Park, 1997.

RADFORD, A. Minimalist Syntax. Cambridge: Cambridge University Press, 2004.

RAPOSO, E. Case Theory and Infl-to-Comp: the Inflected Infinitive in European Portuguese. Linguistic Inquiry 18, p. 85-109, 1987. 